\title{
REDESCRIPTION AND FIRST RECORDS FROM \\ BRAZIL OF DIACYCLOPS URUGUAYENSIS KIEFER \\ (CRUSTACEA, COPEPODA, CYCLOPIDAE)
}

\begin{abstract}
Diacyclops uruguayensis Kiefer, 1935 is redescribed from specimens from Santa Catarina and Ceará, Brazil. These new records represent a significant range extension from southern Uruguay.

KEY WORDS. Copepoda, Cyclopoida, Diacyclops, Brazil, taxonomy, morphology
\end{abstract}

Janet W. Reid ${ }^{1}$

Populations of Diacyclops uruguayensis Kiefer, 1935, were discovered in cultures of leaf litter from a coastal dune forest ("mata de restinga") in the State of Santa Catarina, and in wells in Fortaleza, State of Ceará, Brazil. These are the first encounters since the species was described from southern Uruguay. Species of certain cyclopoid copepod genera such as Acanthocyclops Kiefer, 1927, Diacyclops Kiefer, 1927, Macrocyclops Claus, 1893 and Mesocyclops G.O. Sars, 1914 have shown potential as biological control agents for disease-bearing anopheline mosquitoes (MARTEN et al. 1994). In fact, the collections in Fortaleza were undertaken as part of a survey for potential mosquito control agents (KAY et al. 1992). Because of this applied aspect, and because closely related congeneric cyclopoids often differ markedly in aspects of their biology, detailed morphological descriptions are desirable to aid in their discrimination.

For description, the specimens were transferred from $70 \%$ ethanol to glycerine and then to lactic acid. Drawings were made from specimens mounted temporarily in lactic acid, or permanently in $\mathrm{CMC}-10$ with a little chlorazol black E added, using a Wild M30 microscope fitted with a drawing tube, at magnifications of 600X or 1000X (with an oil immersion lens). The specimens were deposited in the collections of the National Museum of Natural History, Smithsonian Institution (USNM).

\section{Diacyclops uruguayensis Kiefer, 1935}

Figs 1-37

Cyclops (Diacyclops) uruguayensis Kiefer, 1935: 181-184, figs 1-6.

Cyclops uruguayensis Brehm, 1935: 299.

Diacyclops uruguayensis Brehm, 1935: 298, 305, 309. - Dussart, 1984: 65. - Dussart \& Defaye, 1985:

94. - Reid, 1985: 42, 114-115, figs 156-158. - Reid, 1988: 194. - Franke, 1989: 50, 124. -Reid,

1992: 1464. - Pesce, 1995: 14. - Reid \& Strayer, 1994: 256, tab. II.

Acanthocyclops uruguayensis. - Lindberg, 1954: 212-213, 216, tab. XII.

1) Department of Invertebrate Zoology/MRC-163, National Museum of Natural History, Smithsonian Institution. Washington, DC 20560 U.S.A. 


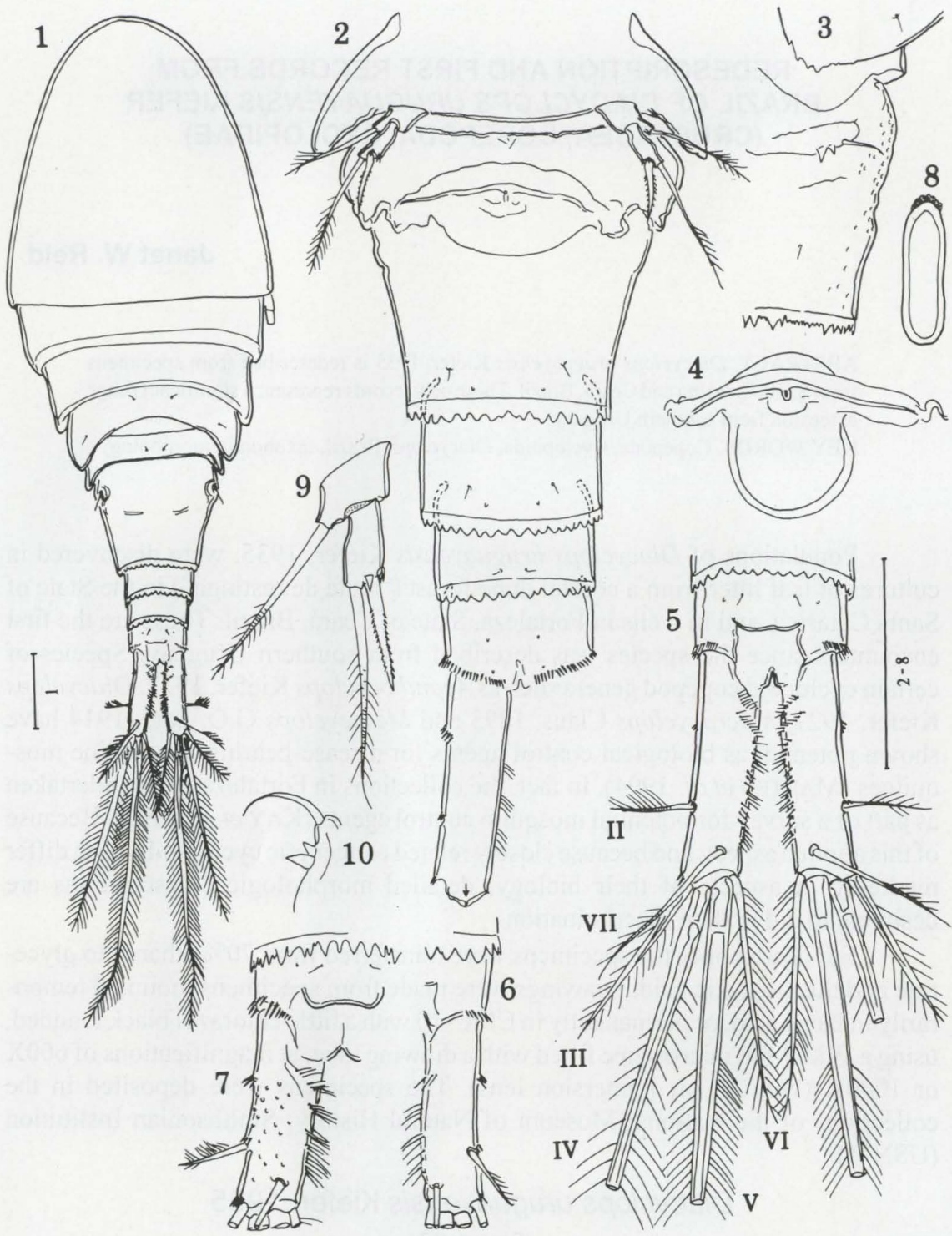

Figs 1-10. Diacyclops uruguayensis female. (1) Habitus, dorsal; (2) pediger 5 and urosome, ventral; (3) pedigers 4-5 and genital double somite, left lateral; (4) seminal receptacle; (5-7) anal somite and caudal ramus, dorsal; (8) spermatophore; (9) leg 5; (10) leg 6. (1, 2, 4, 5, 9, 10) Specimens from Santa Catarina (USNM 283161); ( $3,6,7,8)$ from Ceará (USNM 285463). Scales $=100 \mu \mathrm{m}$.

Material examined. Two females and 1 male, each dissected on slide, and 6 females and 1 male in $70 \%$ ethanol, from culture of leaf litter moistened by groundwater and accumulated rainwater in coastal dune forest ("mata de restinga"), about $300 \mathrm{~m}$ inland from the beach and about $2 \mathrm{~m}$ above sea level, Piçarras, Santa 
Catarina, Brazil, approximately $26^{\circ} 48^{\prime}$ S, $48^{\circ} 41^{\prime} \mathrm{W}, 23$ January 1990 , coll. C.E.F. da Rosha, USNM 283161. From shallow dug wells in Granja Portugal, a suburb of Fortaleza, Ceará, Brazil, approximately $3^{\circ} 43^{\prime} \mathrm{S}, 38^{\circ} 30^{\prime \prime} \mathrm{W}$, February-April 1992, coll. B. H. Kay, C. P. Cabral, Z. M. Ribeiro, and associates: 4 females, Sample 5, Quadro 50, Casa 2032, Rua Duas Nações; 1 female, Sample 7, Quadro 67, Casa 2888, Rua Carlos Chagas; 3 females, Sample 8, Casa 2180; 2 females, Sample 15, Quadro 78, Casa 2375, Rua Riso de Prado; 2 females, Sample 18, well with fish, Casa 3530, Avenida I; 1 female, dissected on slide, Sample 19, Quadro 49, Casa 2075, Rua Souza Carvalho; 7 females, Sample 27, well with fish, Quadro 78, Casa 3541, Rua Riso do Prado (USNM 285463). Other copepod species present: Mesocyclops ellipticus Kiefer, 1936, Sample 5, Quadro 50, Casa 2032, Rua Duas Nações (USNM 285464); Metacyclops sp., Sample 7, Quadro 67, Casa 2888, Rua Carlos Chagas (USNM 285458); Metacyclops cushae Reid, 1991 (USNM 285459), Metacyclops mendocinus (Wierzejski, 1892) (USNM 285456), Microcyclops ceibaensis (Marsh, 1919) (USNM 285460), all from Sample 19, Quadro 49, Casa 2075, Rua Souza Carvalho.

Note: Type material of $D$. uruguayensis was requested from the Staatliches Museum für Naturkunde Karlsruhe, but unfortunately was lost in the mail.

Female. Lengths of Santa Catarina specimens 1.09-1.20 mm, of Ceará specimens 1.04-1.28 mm (Tab. I). Body (Figs 1-3) slender in dorsal view, with lateral margins of pedigers 3-5 produced posteriorly. Posterolateral margins of pedigers 3 and 4 smooth in Santa Catarina specimens, crenate in some Ceará specimens (Fig. 3). Posterior prosomites, urosome, and caudal ramus pitted in some specimens from Ceará (Figs 3, 7). Pediger 5 without surface ornament except for usual two dorsal sensilla. Genital double somite ((Fig. 2) broadest in anterior half, tapering posteriorly, greatest breadth about 1.25 times length. Seminal receptacle (Figs 2,4 ) with anterior margin little produced and strongly sclerotized; posterior expansion little produced to broadly rounded in different specimens; lateral arms broad; pore canal short, straight. Hyaline fringes of urosomites coarsely crenulate (in Santa Catarina and some Ceará females) to dentate (in other Ceará females). Anal somite, posterior margin with slender spinules; anal operculum broad, weakly crescentic, and little sclerotized (in Santa Catarina and some Ceará females) to produced, quadrate, and strongly sclerotized (in other Ceará females); anal sinus smooth.

Caudal ramus (Figs 2, 5-7, Tab. I) about 3.7 times longer than broad in Santa Catarina specimens, about 3.3 times longer than broad in Ceará specimens, ornamented with transverse lateral comb of tiny spinules at anterior $1 / 3$, spinules at bases of lateral seta (II, according to system of HUYS \& BOXSHALL 1991) and lateralmost terminal seta (III) and, in some specimens, at base of medialmost terminal seta (VI), and stiff hairs along most of medial surface, more anterior hairs in rows (Santa Catarina specimens with two rows and two or three ill-defined groups of hairs, Ceará specimens always with two rows and one group of hairs). Apical ventral tip produced, with pore (indicated by arrow in Fig. 2). Seta II inserted at posterior 2/3 of ramus. Lengths of caudal setae as in table I; seta VI consistently longer and seta VII slightly shorter than seta III. Seta V slightly expanded proximal to beginning of plumage. All setae with fine plumage. 
Table I. Measurements ( $\mu \mathrm{m})$ of Diacyclops uruguayensis from Santa Catarina (SC) and Ceará (CE), Brazil. Numbers of specimens measured: SC 8 females and 2 males (USNM 283161); CE 10 females (USNM 285463). Abbreviations: (L) length; (W) width; (CR) caudal ramus; (CR II-VII) caudal setae II-VII [after numbering system of HUYS \& BOXSHALL (1991), Fig. 5]; (P4enp3) leg 4 endopodite segment 3; (P4 m sp) length of P4enp3 medioterminal spine; (P4 I sp) P4enp3 lateroterminal spine; (P6 1-3) lengths of leg 6 (male), innermost to outermost spine or seta respectively.

\begin{tabular}{|c|c|c|c|c|c|}
\hline \multirow{2}{*}{ Structure } & \multicolumn{2}{|c|}{ Females SC } & \multicolumn{2}{|c|}{ Females CE } & \multirow{2}{*}{$\frac{\text { Females SC }}{\text { Lengths }}$} \\
\hline & Median & Range & Median & Range & \\
\hline Body L & 1126 & $1092-1220$ & 1180 & $1040-1284$ & 896,1008 \\
\hline CRL & 137 & $133-142$ & 108 & $98-118$ & 111,116 \\
\hline CR W & 37 & $33-38$ & 33 & $29-35$ & 28,29 \\
\hline CR II & 49 & $42-57$ & 40 & $34-43$ & 43 \\
\hline CR III & 110 & $98-117$ & 82 & $80-92$ & 90,91 \\
\hline CR IV & 354 & $344-376$ & 378 & $348-388$ & 268,296 \\
\hline CR V & 502 & $480-520$ & 534 & $504-540$ & 372,416 \\
\hline CR VI & 153 & $140-161$ & 124 & $113-128$ & 136,144 \\
\hline CR VII & 93 & $90-114$ & 90 & $70-108$ & 93,98 \\
\hline P4enp3 L & 58 & $51-60$ & 52 & $48-55$ & 52,53 \\
\hline P4enp3 W & 34 & $32-36$ & 31 & $29-34$ & 27 \\
\hline P4 m sp & 49 & $43-51$ & 43 & $38-50$ & 43,51 \\
\hline P4 I sp & 64 & $56-66$ & 60 & $53-60$ & 52,61 \\
\hline P6 1 & - & - & - & - & 42,43 \\
\hline P6 2 & - & - & - & - & 31,33 \\
\hline P6 3 & - & - & - & - & 82,83 \\
\hline
\end{tabular}

Antennule (Figs 11, 12) of 17 segments, reaching midlength of pediger 2. Surface of segments smooth except for short comb of spinules on segment I. Segments (Roman numerals) with number of setae (Arabic numerals), spines, and aesthetascs in parentheses: I(8), II(4), III(2), IV(6), V(3+aesth.), VI(1+spine), VII(2), VIII(1), IX(1), X(0), XI(1), XII(1+aesth.), XIII(0), XIV(1), XV(2), XVI (2+aesth.), XVII (7+aesth.). Spine on segment VI slender. Segments XVI and XVII each with narrow, finely toothed hyaline membrane; membrane of segment XVII extending from lateral seta to near distal end of segment.

Antenna (Figs 13-15), basipodite with several groups of spinules on both frontal and caudal surfaces, pattern in Ceará specimens simpler; endopodite segments $1-3$ with 1,9 , and 7 setae respectively.

Labrum (Figs 16, 17) with 9-11 marginal teeth between lateral corners; ventral side with two groups of long hairs and two transverse rows of tiny denticles, teeth of anterior row fewer and larger. Mandible (Fig. 18), palp with one short and two long setae. Maxillule (Fig. 19), surface of palp smooth. Maxilla (Figs 20, 21), claw with double row of teeth along inner margin, Ceará specimens with fewer teeth than Santa Catarina specimens. Maxilliped (Fig. 22), segment 2 with three rows of spinules along caudal surface; seta on segment 3 and proximalmost seta on segment 4 stout, spiniform. Lengths of broken setae on terminal segment of maxilla (Fig. 20) and segment 1 of maxilliped (Fig. 22) estimated by comparison with another specimen. 


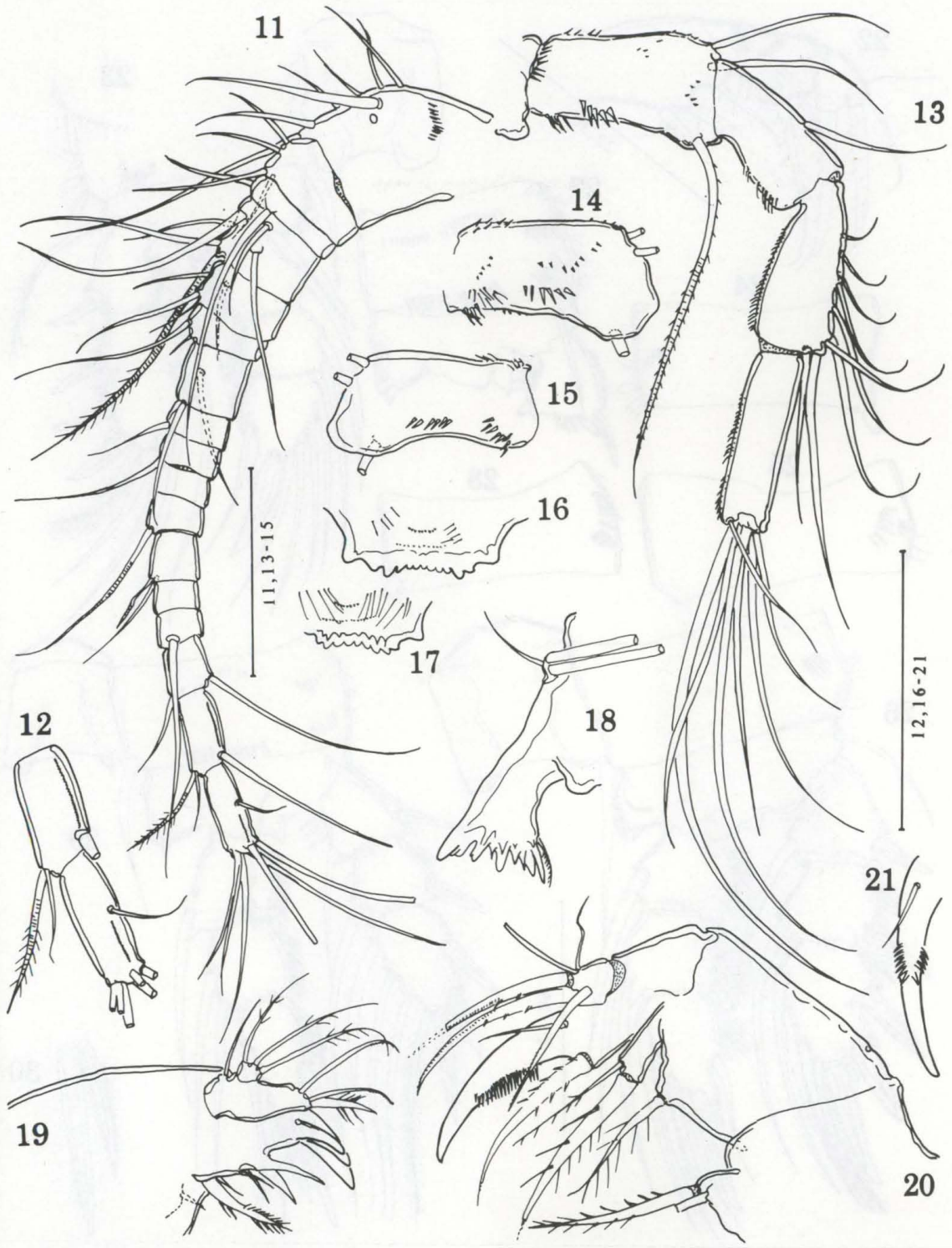

Figs 11-21. Diacyclops uruguayensis female. (11) Antennule; (12) antennule segments XVIXVII; (13) antenna, frontal; (14-15) antenna basipodite, caudal; (16-17) labrum; (18) mandible; (19) maxillule; (20) maxilla; (21) claw of maxilla, inner margin. (11-14, 16, 18-20) Specimens from Santa Catarina (USNM 283161), $(15,17,21)$ from Ceará (USNM 285463). Scales = $100 \mu \mathrm{m}$.

Legs 1-4 (Figs 23-30) with three-segmented rami, although some specimens from Santa Catarina with indistinct suture between leg 1 exopodites 2 and 3 (Fig. 23). Couplers (intercoxal sclerites) of all legs lacking surface ornamentation, but with two rounded marginal protrusions, protrusions of leg 4 narrowest and most 


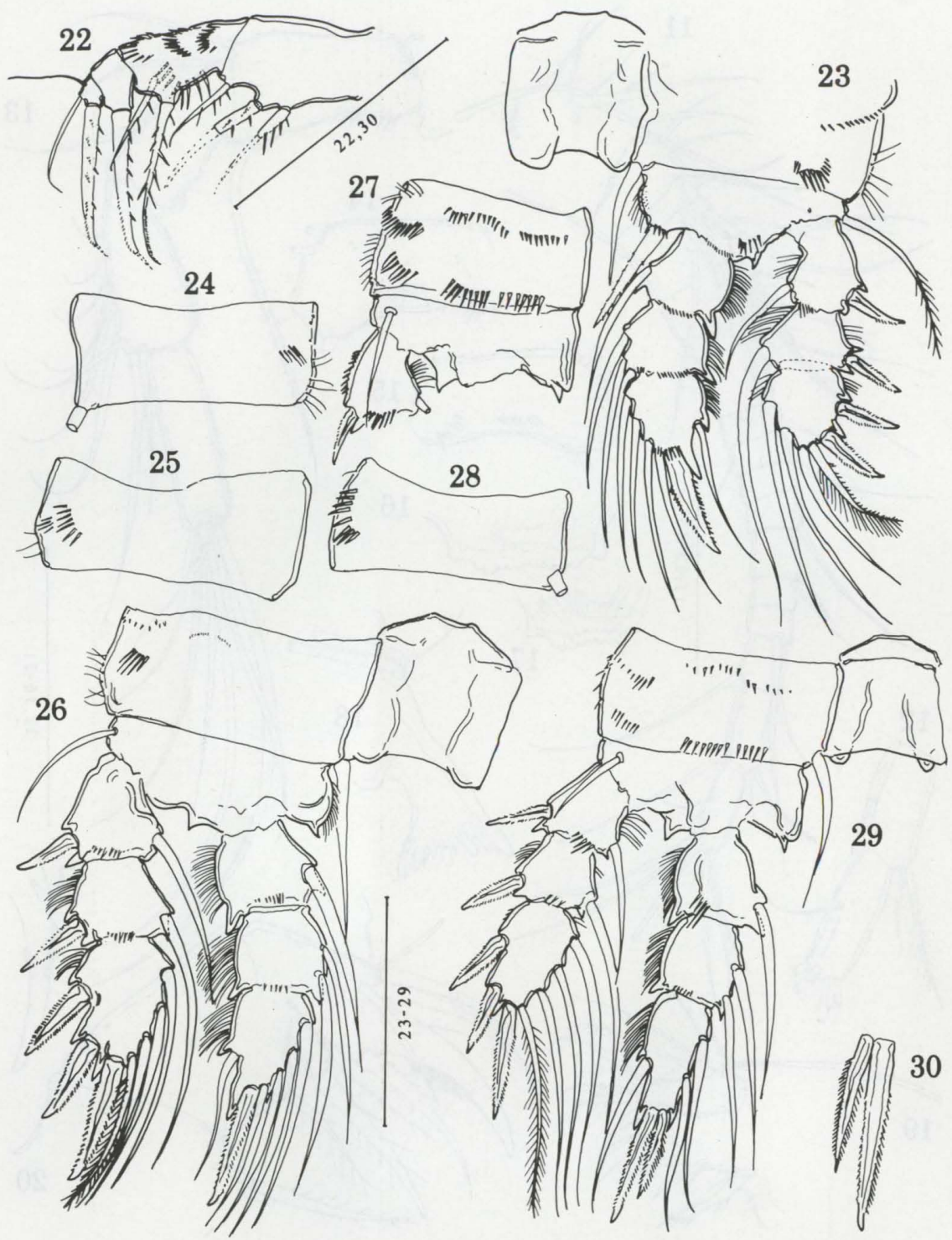

Figs 22-30. Diacyclops uruguayensis female. (22) Maxilliped; (23) left leg 1 and coupler, frontal; (24) leg 1 coxopodite, caudal; (25) leg 2 coxopodite, frontal; (26) left leg 2 and coupler, caudal; (27) leg 4, coxa-basipodite and exopodite segment 1, caudal; (28) leg 4 coxopodite, frontal; (29) left leg 4 and coupler, caudal; (30) right leg 4 endopodite segment 3 , terminal spines (enlarged). (22-26, 28-30) Specimens from Santa Catarina (USNM 283161), (27) from Ceará (USNM 285463): Scales $=100 \mu \mathrm{m}$.

pronounced. Segment 3 of exopodites 1-4 with 2,3,3,3 spines and 4,4,4,4 setae respectively. Leg 1 with finely dentate spine on medial expansion of basipodite. Legs 2 and 3 similar except leg 3 slightly larger; exopodite segment 1 of each with 
posterior surface sculptured. Leg 4 basipodite, medial margin smooth, its posterior surface sculptured; exopodite segment 1 with smooth lateral margin in Santa Catarina specimens, spinulate lateral margin in Ceará specimens; endopodite segment 1 sculptured; endopodite segment 3 about 2.4 times longer than broad in Santa Catarina specimens, 1.7 times in Ceará specimens, with two terminal spines, medial spine shorter than lateral spine and slightly sprung medially.

Leg 5 (Figs 2,9) with medioterminal spine serrate, longer than distal segment, with few spinules at base. Leg 6 (Figs 3,10) with short dorsal seta and two large spines.

Egg sacs of two Ceará females with 11/12 and 18/18 eggs. Spermatophore (Fig. 8) long-oval.

Male: Lengths of Santa Catarina specimens 0.89 and $1.01 \mathrm{~mm}$. Body (Fig. 31) slender. Caudal ramus (Fig. 32) 4 times longer than broad, ornamentation and proportions of setae much as in female.

Antennule (Fig. 33) geniculate, of 16 segments, segments I, IV, and IX with 4,1 , and 1 short aesthetases respectively.

Antenna (Fig. 34) as in female except spinule pattern on basipodite somewhat simpler, and endopodite segment 2 with 8 setae.

Labrum, mouthparts, and legs 1-4 as in female, except leg 2 exopodite segment 1 (Fig. 35), lateral spine extended laterally and rotated anteriorly; and leg 4 endopodite segment 1 (Fig. 36) not sculptured.

Leg 6 (Fig. 37) bearing medial, finely serrate spine and two plumose setae, lengths given in table I. Surface of leg with row of few spinules medial to spine, longer diagonal row of spinules, and large pit at medial end of this row.

\section{DISCUSSION}

The specimens from Santa Catarina and Ceará agree with the description of KIEFER (1935), except that the body length (1.2-1.4 mm in Uruguayan specimens), the presence of crenulation on the posterolateral margins of pedigers 3 and 4 , the shape of the anal operculum, the proportions of the caudal ramus ( 4.5 times longer than broad in Uruguay), the arrangement of the medial hairs on the caudal ramus (with three rows and one or two groups of hairs in Uruguay), the antenna basipodite and leg 4 coxopodite spinule patterns, and the proportions of leg 4 endopodite segment 3 are now seen to be rather variable.

Diacyclops hispidus Reid, 1988, from Colombia, greatly resembles $D$. uruguayensis, but differs in having short spinules rather than long "hairs" on the medial surface of the caudal ramus, and only three groups of these spinules, all in defined rows; the maxilliped segment 2 with only two rows of spinules along the caudal surface; the medioterminal spine of leg 4 endopodite segment 3 a little longer, relatively, than the corresponding spine in D. uruguayensis; and the middle seta on leg 6 of the male quite short. The geographically nearer, northern (Ceará) population of $D$. uruguayensis certainly tends toward a closer resemblance to D. hispidus, having shorter and less elaborately ornamented caudal rami than the more southern 
populations. Final judgment as to whether these differences are sufficient to justify maintaining $D$. hispidus as a separate taxon must await the discovery and analysis of geographically intermediate populations.

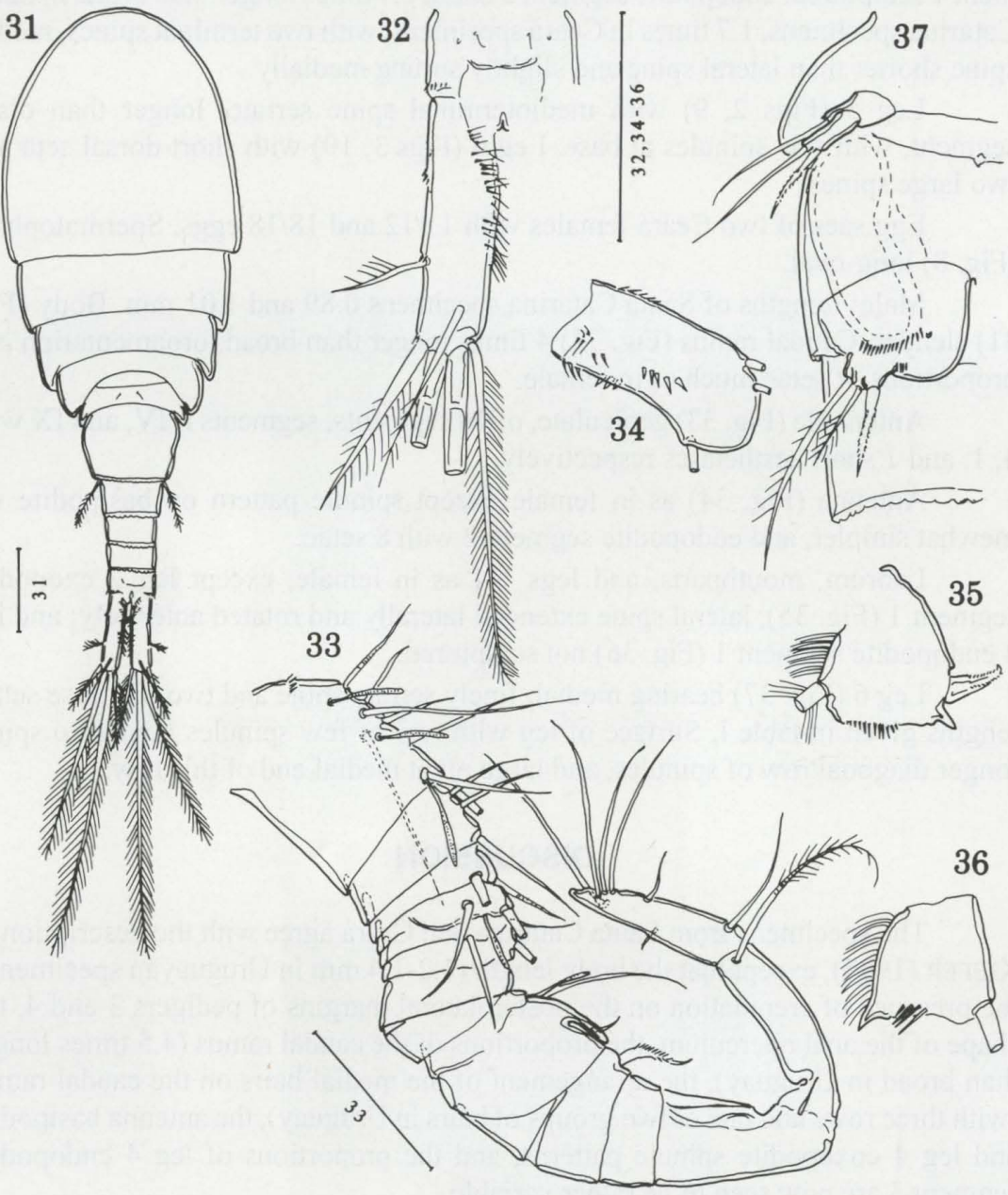

Figs 31-37. Diacyclops uruguayensis male, from Santa Catarina (USNM 283161). (31) Habitus, dorsal; (32) anal somite and caudal ramus, dorsal; (33) antennule (some setae omitted); (34) antenna basipodite, caudal; (35) leg 2 exopodite segment 1 ; (36) leg 4 endopodite segment 1; (37) legs 5 and 6, ventral. Scales $=100 \mu \mathrm{m}$.

Although both taxa seem to occur mainly near the South American coastline, they may differ slightly in salinity preference. KIEFER (1935) decribed D. uruguayensis from drains and a temporary pool between Montevideo and Santa Lucia, Uruguay. BREHM (1935) gave additional records from a small stream pool on the shore of the Rio de la Plata at Pajas Blancas, a house drain, and ditches at Tarjan. 
These collections were apparently from fresh water. Although no salinity measurements were made, the accompanying fauna in the Santa Catarina collection was exclusively freshwater (C.E.F. da Rocha, personal communication), as were the other copepod species in the Ceará wells. On the other hand, D. hispidus was collected in shallow brackish water near the Colombian coast (REID 1988).

The extended, rotated lateral spine of leg 2 exopodite segment 1 seen in the male of D. uruguayensis seems to be a widespread feature in Mesocyclops and Diacyclops (KIEFER 1981; DAHMS \& FERNANDO 1993; Fiers et al. 1996).

Diacyclops uruguayensis has not been encountered since the original description by KIEFER (1935) and additional records given by BREHM (1935), all from Uruguay. The present report considerably extends the known geographical range of this species northwards along the coast of Brazil.

The genus Diacyclops has few representatives in South America, and for that matter in the neotropics. Acanthocyclops michaelseni (MRÁzEK 1901), by some (e.g. MoRTON 1985) considered a member of Diacyclops, is widespread in Argentina, Chile, and the Falklands/Malvinas (Menu MARQUe 1991). Diacyclops uruguayensis and D. hispidus are the only other South American species, and three additional species are known from Central America, the Yucatán Peninsula of Mexico, and San Andrés Island (reviewed by FIERS et al. 1996). All the neotropical species inhabit ephemeral surface waters, or groundwaters (wells, caves, and cenotes).

The find of Metacyclops cushae, previously known from Louisiana in the southern U.S.A. and from Honduras, is the first from Brazil. This record was already mentioned by ROCHA (1994).

ACKNOWLEDGEMENTS. I am most grateful for gifts of specimens to the collections of the National Museum of Natural History by Drs. Brian H. Kay and Carlos E. F. da Rocha. The manuscript benefited from helpful comments by Dr. da Rocha and an anonymous reviewer. The collectors who collaborated with Dr. Kay are heartily thanked. The Department of Invertebrate Zoology, National Museum of Natural History afforded me research facilities.

\section{REFERENCES}

BREHM, V. 1935. Über die Süßwasserfauna von Uruguay. Arch. Hydrobiol. 28: 295-309.

DAHMS, H.-U. \& C.H. FERNANDO. 1993. Redescription of Mesocyclops leuckarti (Copepoda, Cyclopoida), including a study of its naupliar development. Int. Revue ges. Hydrobiol. Hydrogr. 78 (4): 589-609.

DussarT, B.H. 1984. Some Crustacea Copepoda from Venezuela. Hydrobiologia 113: $25-67$.

Dussart, B.H. \& D. Defaye. 1985. Répertoire Mondial des Copépodes Cyclopoïdes. Bordeaux, Éditions C.N.R.S., 236p.

Fiers, F.; J.W. REID; T.M. IlifFe \& E. SuÁREZ-Morales. 1996. New hypogean cyclopoid copepods (Crustacea) from the Yucatán Peninsula, Mexico. Contr. Zool., Amsterdam, 66 (2): 65-102. 
FRANKE, U. 1989. Katalog zur Sammlung limnischer Copepoden von Prof. Dr. Friedrich Kiefer. Carolinea, Karlsruhe, 5: 1-433.

HuYs, R. \& G.A. Boxshall. 1991. Copepod Evolution. London, The Ray Society, $468 \mathrm{p}$.

Kay, B.H.; C.P. Cabral; D.B. Araújo; Z.M. Ribeiro; P.H. Braga \& A.C. SLEIGH. 1992. Evaluation of a funnel trap for collecting copepods and immature mosquitoes from wells. Jour. Amer. Mosq. Control Ass. 8 (4): 372-375.

KIEFER, F. 1935. Neue Süßwassercyclopiden (Crustacea Copepoda) aus Uruguay. Zool. Anz. 109 (7-8): 181-188.

. 1981. Beitrag zur Kenntnis von Morphologie, Taxonomie und geographischer Verbreitung von Mesocyclops leuckarti auctorum. Arch. Hydrobiol., Suppl. 62 (Monogr. Beitr.), 1: 148-190.

LindBERG, K. 1954. Cyclopides (crustacés copépodes) de l'Amérique du Sud. Ark. Zool., N. S., 7 (11): 193-222.

MARTEN, G.G., E.S. Bordes \& M. NGUYEN. 1994. Use of cyclopoid copepods for mosquito control. Hydrobiologia 292/293: 491-496.

Menu MARQue, S. 1991. Los copépodos del genero Acanthocyclops de Tierra del Fuego. Biol. Acuática 15: 142-143.

Morton, D.W. 1985. Revision of the Australian Cyclopidae (Copepoda: Cyclopoida), I. Acanthocyclops Kiefer, Diacyclops Kiefer and Australocyclops, gen. nov. Austr. Jour. Mar. Freshw. Res. 36: 615-634.

MRÁZEK, A. 1901. Süsswasser-Copepoden. Ergebn. Hamburger Magalhaensische Sammelreise 6: 1-29.

Pesce, G.L. 1995. The genus Diacyclops Kiefer in Italy: a taxonomic, ecological and biogeographical up-to-date review (Crustacea Copepoda Cyclopidae). Arthropoda Selecta 3(3-4): 13-19.

REID, J.W. 1985. Chave de identificação e lista de referências bibliográficas para as espécies continentais sulamericanas de vida livre da ordem Cyclopoida (Crustacea, Copepoda). Bolm Zool., Univ. São Paulo 9: 17-143.

. 1988. Cyclopoid and harpacticoid copepods (Crustacea) from Mexico, Guatemala, and Colombia. Trans. Amer. Microsc. Soc. 107: 190-202.

1992. Redescription of Diacyclops nearcticus (Kiefer, 1934) and description of four similar new congeners from North America, with comments on D. crassicaudis (G.O. Sars, 1863) and D. crassicaudis var. brachycercus (Kiefer, 1927) (Crustacea: Copepoda). Can. Jour. Zool. 70 (7): 1445-1469.

REID, J.W. \& D.L. STRAYER. 1994. Diacyclops dimorphus, a new species of cyclopoid copepod from Florida, with comments on morphology of interstitial cyclopine cyclopoids. Jour. N. Amer. Benthol. Soc. 13 (2): 250-265.

RocHA, C.E.F. DA. 1994. New species of Metacyclops (Copepoda, Cyclopidae) from Brazil, with remarks on M. campestris. Zoologica Scr. 23 (2): 133-146.

Recebido em 20.VI.1997; aceito em 05.VIII.1998. 